\title{
Образ Иисуса Христа в тексте и контексте романа «На ножах» Н. С. Лескова
}

\author{
Наталья Н. Старыгина (Yoshkar-Ola)
}

\begin{abstract}
Аннотация
В статье выявляются актуальные для романа Н.С. Лескова «На ножах» способы и приемы формирования христианского контекста, формой представленности которого является символическое пространство романного текста. Образ-символ Иисуса Христа как основное средство формирования контекстуального содержания центрирует христианские смыслы, мотивы, образы, символы, определяя семантическое наполнение символического пространства. Образ Христа функционирует в тексте благодаря созданной автором словесной иконографии и «евангельского текста». Поэтическими приемами введения в текст образа Христа являются упоминание, называние, именование, цитата, реминисценция, аллюзия и др. Они также выступают маркерами христианских мотивов, концептов, идеологем. Образ-символ Христа и сопутствующие ему смыслы, мотивы, образы способствуют воплощению и выражению авторского мировосприятия и понимания человека.
\end{abstract}

\section{Ключевые слова}

христианский контекст; образ-символ; контекстуальная поэтика

\section{Abstract \\ The image of Jesus Christ in Text and Context the Novel "On Knives" of N. S. Leskov}

The article reveals the methods and techniques of formation of the Christian context, the form of representation of which is the symbolic space of the novel text, which are actual for N. S. Leskov's novel "On knives". The image-symbol of Jesus Christ as the main means of formation of contextual content centers the Christian meanings, motives, images, symbols, defining the semantic content of the symbolic space. The image of Christ functions in the text thanks to the verbal iconography and the "gospel text" created by the author. Poetic methods of introducing the image of Christ into the text are mention, naming, naming, quotation, reminiscence, allusion, etc. They also act as markers of Christian motives, concepts, ideologies. The image-symbol of Christ and the accompanying meanings, motives, images contribute to the embodiment and expression of the author's worldview and understanding of man.

\section{Key words}

Christian context; the image of the symbol; contextual poetics 
Роман Н. С. Лескова «На ножах» (1870-1871) мы рассматриваем в ряду антинигилистических романов 1860-1870-х гг., выразивших идеи и идеалы антинигилистического движения в России в ситуации философско-религиозной полемики между «постепеновцами» и «нетерпеливцами» (говоря словами Н. С. Лескова) русского общества. Содержание антинигилизма определялось христианским учением и неприятием инонациональных для значительной части российского общества позитивистских, материалистических, атеистических идей, составивших содержание русского нигилизма ${ }^{1}$. Христианство определило не только тематику, проблематику и идеологию антинигилистических романов, но и их поэтику (композиционно-сюжетное решение, расстановку персонажей, средства, способы и приемы создания художественной картины мира и др.). Важно отметить, что восприятие читателем произведений этой жанровой разновидности русского романа обусловлено общим для них христианским контекстом. При этом из разнообразных форм представленности контекстуального содержания авторы конкретных антинигилистических романов выбирают те, которые соответствуют специфике их собственной поэтики. Однако символический план повествования (как одна из форм представленности контекстуального содержания), в котором бытуют христианские образы-символы, формируется в каждом произведении. Христианские символы становятся важнейшим средством актуализации в сознании читателя христианских смыслов, ценностей, образов, мотивов и т.д. Среди христианских символов центральным является образ Иисуса Христа, присутствующий в художественном мире антинигилистических романов как выражение христианского этико-эстетического идеала. Это обусловлено тем, что для верующих людей Иисус Христос - совершенный человек, «новый Адам» и, как сформулировал Ф. М. Достоевский, «идеал, к которому стремится и по закону природы должен стремиться человек [...] после появления Христа, как идеала человека во плоти, стало ясно [...] что Христос - великий и конечный идеал развития всего человечества - представленный нам, по закону нашей истории, во плоти [...] Христос весь вошел в человечество, и человек стремится преобразиться в Я Христа, или в свой идеал»². Учение Иисуса Христа определяет мировосприятие и, конечно, нравственное чувство верующего человека. Г. П. Федотов подчеркивал, что «образ Христа и заповеди Его любви глубоко врезались в память и сердие русского народа. Греша и падая, в своей жестокой и кровавой истории, русский народ не мог расстаться с этим Божественным образом. Он согревал его жизнь, смягчая человеческие отношения жалостью и прошением, уча видеть в бедном и страдающем не только брата, но и самого Христа, томя сердие жаждой иной, светлой жизни, в полноте осуществляющей заветы братской любви» ${ }^{3}$.

1 См. об этом: STARYGINA, N. N.: Russkij roman v situacii filosofsko-religioznoj polemiki 1860-1870-h godov. Moskva: YAzyki slavyanskoj kul'tury, 2003. 352 c.

2 Neizdannyj Dostoevskij: Zapisnye knizhki i tetradi 1860-1881 gg. AN SSSR. In-t mirovoj lit. im. A.M. Gor'kogo. Red. I. S. Zil'bershtejn - L. M. Rozenblyum. V podgot. toma k pech. prinimala uchastie F. I. Grinberg; Podbor il. N. D. Efros pri uchastii G. F. Kogan. Moskva: Nauka, 1971, c. 173.

3 FEDOTOV, G. P.: Social'noe znachenie hristianstva. Ego zhe. Tyazhba o Rossii. Stat'i 1933-1936. Parizh, 1982, c. $41-42$. 
Таким образом, в сознании представителей российского социокультурного пространства, культурным ядром которого является христианство, образ Иисуса Христа присутствует как „вещий знак“ (А. Блок), символ, не нуждающийся в расшифровке или декодировании.

Роман «На ножах» Н. С. Лескова характеризуется плотным и насыщенным символическим пространством, в котором образ Иисуса Христа активно центрирует важнейшие христианские идеи, мотивы, образы, составляющие контекст произведения. При этом в тексте довольно объемного романа не так много непосредственных указаний на этот образ. К их числу относится своего рода словесная иконография Иисуса Христа.

Автор вводит в текст образ-символ Христа, обращая внимание читателя на знаковую для быта религиозного человека вещь - икону. Действительно, иконы Иисуса Христа есть во всех домах христиан, занимая почетное место в домашнем иконостасе. Икона Христа соединяет земного человека с Царствием Небесным. К иконе Христа обращаются с молитвой в самых трудных духовных и житейских ситуациях с верой и надеждой на спасение. Икон Иисуса Христа много, чаще всего Спаситель изображается с крестчатым нимбом на голове, являющимся символом Божественного света. Таким образом указывается на две сущности Иисуса Христа: Его небесное, божественное начало и земное, человеческое. Часто Христос изображается держащим открытую или закрытую Библию, которая сообщает человечеству о том, что Всевышний несет людям спасение.

В романе иконы с изображением Христа упоминаются, называются и именуются. Таких упоминаний немного: «... на Горданова глядел благой, успокаиваюший лик Спасителя» (Т. 9, с. 20) ${ }^{4}$; «образ Христа» (Т. 9, с. 381); «изображение распинаемого на Голгофе Христа» (Т. 8, с. 416); «лик Нерукотворного Спаса» (Т. 9, с. 368).

Самое нейтральное упоминание (именование) иконы - «образ Христа» (слово «образ» выступает здесь синонимом к слову «икона»). Однако оно содержательно емкое, поскольку включает все смыслы христианского учения, которые могут быть актуальны для читателя, автора-повествователя, героев произведения. Внутренний контекст ситуации, создаваемый содержанием диалога героев романа Синтяниной и Подозерова и воспоминанием о генерале Синтянине, вернувшемся в лоно Церкви, актуализирует в образе Христа смыслы, позволяющие рассматривать его символом духовного перерождения и возрождения, символом веры, возрастания души, символом спасения.

Образ Христа как символ спасения соотнесен с мотивом спасения, одним из сквозных в романе «На ножах. Данный мотив обозначен еще одним указанием на икону Христа: «благой, успокаивающий лик Спасителя». Здесь, прежде всего, важно «говорящее» именование «Спаситель». Не менее важен внутренний контекст ситуации. Одержимому преступными замыслами Павлу Горданову в полутемной комнате привиделся «образ» Христа, под которым находилось «зеленое

4 LESKOV, N. S.: Na nozhah. Leskov N. S. Sobr. soch.: V 12 t. - T. 8-9. - Moskva: Izd-vo «Pravda», 1989. Цитирую по этому издании., указывая в скобках том и страницу. 
женское платье» (Т. 9, с. 20). Образ зеленого платья является в романе авторским символом, указывающим на преступность замыслов Павла Горданова и Глафиры Бодростиной, на аморальность героев, их тревожное душевное состояние и др. Образ зеленого платья своего рода образ-предупреждение; образ, призванный остановить злодеяния героев; образ, вызывающий сомнения, колебания и тревогу в душах героев. В этом плане иконописный образ Христа контрастен образу зеленого платья: вера в Христа несет благо душе, спокойствие, открывает возможность спасения души. Второе в этом фрагменте именование иконы «лик» соответствует возвышенному духовному состоянию, в котором пребывает верующий человек, свидетельствует о торжестве веры, передает чувства умиротворенности, благости и благодарности. Такого рода атмосфера противоположна состоянию суетности и суетливости, душевного неспокойствия и раздерганности, в котором пребывают Горданов и Бодростина.

Икона Христа - «лик Нерукотворного Спаса» - упоминается как ритуальная вещь, необходимая во время панихиды по усопшему графу Бодростину. При этом «... в христианском мире легенды о нерукотворных образах повествуют о разных пролвлениях земного служения Спасителя» ${ }^{5}$. Возможно, в данном эпизоде икона служит напоминанием о земной жизни человека, которая может завершиться или чудом спасения души, или гибелью души.

Символика иконы, на которой изображен «распинаемый на Голгофе Христос», чрезвычайно богата. Данным образом обозначены мотивы греха, ожидания Страшного суда, спасения и/или погибели души, нравственного выбора, актуальные для лесковского романа. Икона упоминается в контексте описания переживаний Ларисы Висленевой, оказавшейся «на распутьи», боящейся страсти Горданова и уже одержимой этой страстью. Лариса «иасто взглядывала» (Т. 8, c. 416) на икону, и, казалось бы, героиня приняла решение: «Лара вздохнула и, оборотясь к образу, тихо встала на колени и заплакала и молилась, молилась словами тетки и вдруг потеряла их» (Т. 8, с. 416). Известная сцена утраты молитвы, утраты героиней способности молиться, то есть утраты духовной связи с Христом (ср., например, с аналогичным эпизодом в романе И. А. Гончарова «Обрыв»), предшествует эпизоду грехопадения Ларисы.

Евангельский сюжет распятия Иисуса Христа вводит в символический план романа «закрепленные» за ним христианские символы. Некоторые из них позволяют увидеть в реалиях, изображенных автором, символический смысл. Другие материализуются в персонажах, предметных деталях, цвете, пространственных характеристиках, именах, получая новую жизнь в контексте содержания романа, приобретая новую символическую семантику.

К первым относится образ Голгофы (место распятия Христа, лобное место, сакральный центр мира), благодаря которому современная автору Россия может быть осмыслена как центр мира и лобное место, где своей кульминации достигла борьба добра и зла, света и тьмы, Христа и Антихриста.

5 KOLESNIKOVA, V. S.: Pravoslavnyj hram. Simvolika i tradicii. Moskva: OLMA-PRESS, 2006, c. 223. 
Ко вторым относятся образы двух разбойников, распятых справа и слева от Иисуса Христа, - раскаявшегося и нераскаявшегося. Образ раскаявшегося разбойника ассоциируется с образами генерала Синтянина, Ларисы Висленевой, осознавшими свои грехи, просветлевшими душой. Образ нераскаявшегося разбойника соотносится с образами героев, представителей «темных сил» (Висленев, Кишенские и др.).

В символическое пространство романа благодаря упоминанию иконы о распятии Христа вводится образ Креста как символ христианства и жертвы Христа, как символ веры и символ крестного пути человека, его крестной ноши. Вероятно, читатель, знающий сюжет распятия Иисуса Христа, неизбежно введет в контекстуальное содержание романа символику образов крови и пяти ран Христа. Кровь Христа наделяется в христианстве искупительной силой, а раны Христовы символизируют победу духа над телом.

Символические образы, связанные с трагической историей распятия Иисуса Христа, - внетекстовая сфера романа «На ножах», сформированная контекстуальным содержанием. Но именно изображенные Лесковым в романе события и герои, созданная им полярная модель мира («светлые» и «темные» силы) актуализируют христианские мотивы, образы, смыслы.

Создавая иконографию, автор, как правило, не раскрывает содержание икон. Его лаконичность мотивирована тем, что для лесковских героев, верующих и неверующих, икона - неотъемлемая и привычная сторона повседневной жизни, а содержание икон - образов Христа - было известно каждому из них. Но для воцерковленных персонажей иконописное изображение Иисуса Христа имеет особый статус: в нем сосредоточены ответы на вечные вопросы о смысле жизни, о выборе своего «креста», о чести и достоинстве и т.д. «Во Христе-Богочеловеке наша иконопись итит и изображает тот новый жизненный смысл, который должен наполнить все» ${ }^{6}$. Икона передает «то самое, что составляет высшее средоточие духовной жизни человеческоголии [...] такие душевные настроения, как пламенная надежда, или успокоение в Боге» ${ }^{7}$.

Введение образа Христа через словесную иконографию выявляет духовно-нравственный подход к изображению мира и человека в романе Лескова. Образ Христа - символ духовного и нравственного совершенства с соответствующим комплексом этико-эстетических идей, определяющих земную жизнь человека. Икона - «умозрение в красках» - сообщает эту информацию, формируя религиозно-этическую проблематику произведения. Герои романа (и читатели) воспринимают название или описание иконы в контексте нравственно-эстетических идей, сопутствующих образу Иисуса Христа. В сознании героев-атеистов иконописное изображение Христа существует в качестве символа отвергаемой христианской веры, оно

6 TRUBECKOJ, E. N.: Tri ocherka o russkoj ikone. Umozrenie v kraskah. Dva mira v drevnerusskoj ikonopisi. Rossiya v ee ikone. Novosibirsk, 1991, c. 28 URL: http:/ / lib.ru/CULTURE/TRUBECKOJ/ikony.txt

7 TRUBECKOJ, E. N.: Tri ocherka o russkoj ikone. Umozrenie v kraskah. Dva mira v drevnerusskoj ikonopisi. Rossiya v ee ikone. Novosibirsk, 1991, c. 17. 
не является для них средоточием духовной жизни. В целом «икона играет роль мистического посредника между миром земным и миром небеснљм» ${ }^{8}$.

Наряду со словесной иконографией в контекстуальной поэтике романа «Н ножах» важное значение для выявления символических смыслов образа Христа имеет «евангельский текст». Он формируется цитатами, реминисценциями, аллюзиями, которые можно сгруппировать вокруг основных христологических идей и мотивов.

Образ Христа - символ великой жертвы ради спасения человечества. О великом подвиге Иисуса Христа в романе говорит отец Евангел: «в Гефсиманском саду случилось другое: там Бог сам себя предал страданълм» (Т. 9, с. 77). Эти слова адресованы гостям «поэтического попа» (Т. 9, с. 78): чете Форовых, генеральше Синтяниной, Ларисе Висленевой. Эпизод гостевания в семье буквально соткан из разного рода цитации евангельских и иных христианских источников.

Образная оппозиция, структурирующая эпизод, - сад/город. В саду Евангела царят «покой деревъев, трав и иветов, облитых бледно-желтоватым светом луны», «таинственные звуки полуночи» (Т. 9, с. 77). Звуки природы отчетливо слышны, потому что далеко отсюда до «человеческой злобъ» (Т. 9, с. 77). Отец Евангел, опираясь на тексты Гете и А. К. Толстого, утверждает, что таинственные ночные звуки «выманивают нас петь на волю из-под сарая» (Т. 9, с. 77). (Герой намекает на произведение «Ночные песни странников» Гете, неточно цитирует поэму «Иоанн Дамаскин» А. К. Толстого.) Внутреннее противопоставление в высказывании: воля (природа) - несвобода (сарай). Образ сарая - авторский символ, выражающий мысль о том, что повседневность с её рутинным бытом, мелочами жизни, привычными хозяйственными заботами и хлопотами часто «засоряет» духовное зрение человека, приземляет его, погружает в быт. (Писатель любил создавать подобные образы-символы. Достаточно вспомнить образ души-«амбара», созданный им в «рассказе кстати» «Старинные nсихопать».) Данная оппозиция нюансирует структурирующую эпизод гостевания оппозицию сад/город.

Образу сада, где возвышается дух человека, размышляющего о мироздании и Боге, противопоставлен образ города как символ бездуховности и бездушия. (Ср. образ Петербурга в романе И. А. Гончарова «Объкновенная история».) В анализируемом эпизоде сначала упоминается Париж, где царят «звуки Марсельезъ в рабочих уличах» (Т. 9, с. 77). (Это слова «честного нигилиста» майора Форова.) Образ революционного Парижа - явная аллюзия на современное российское общество, увлеченное идеями революции и демократии. Затем возникает образ первого библейского города: «Первый город на земле сгородил Каин, он первый и брата убил. Заметьте, - создатель города есть и твореи смерти» (Т. 9, с. 77), - говорит отец Евангел. Образ города становится символом зла, тьмы и смерти, «брожения» духа, отступления от веры, гордыни (возможно, автор, создавая звуковые об-

8 RAJGORODSKIJ, L. D.: Ikonopis'i zhivopis'. Ikona i kartina. Vestnik Sankt-Peterburgskogo gosudarstvennogo universiteta. Seriya 15. SPb., 2014. Vyp. 1., c. 127. [Elektronnyj resurs]. -URL:https:/ / cyberleninka.ru/ article/n/ikonopis-i-zhivopis-ikony-i-kartiny/viewer 
разы повторением город - сгородил - города, стремился сформировать у читателя данную ассоциацию) и др.

Оппозиция сад/город соотносится с общей топосной оппозицией в художественном пространстве романа: столица - провинция.

В контексте этого противопоставления очевидной становится и позиция героя романа, отца Евангела, и позиция автора: «Париж! Город! - воскликнул с кротким предостережением Евангел. - Нет, нет, не ими освятится вода, не они раскуют мечи на орала! [...] кроткие наследят землю. Нет, сестры и братья, множитесь, населяйте землю и садите в нее семена, а не башенъе стройте, ибо с башен смешенъе идет» (Т. 9, с. 77).

Намек на легенду о строительстве Вавилонской башни (Быт 11, 1-9) - еще один смысловой штрих в символике образа города как средоточия зла, тьмы и смерти.

Основная мысль Евангела («не ими освятится вода, не они раскуют мечи на орала! [...] кроткие наследят землю»), выраженная с помощью аллюзий и реминисценций, заключается в утверждении того, что спасение человечества - в вере в Бога, в духовном совершенствовании, в следовании Христу и в приближении к Нему как к идеалу. Она подтверждается внутренним противопоставлением в образе-символе сада: Эдемский сад (см. Быт 3) и Гефсиманский сад (см. Мф 26, 36-46). В Эдемском саду - земном раю - «дяявол убедил человека не слушаться Бога» (Т. 9, с. 77), «но зато в Гефсиманском саду случилось другое: там Бог сам себя предал страданьям» (Т. 9, с. 77). Спаситель взял на себя «тяготы» человечества, поэтому Его «закон» - «тяготь друг друга носите» (Т. 9, с. 78) («Носите бремена друг друга и таким образом исполните закон Христа» (Гал 6, 2). Великую искупительную жертву Христа лишены способности понять те, кто говорит «несть Бољ» (Т. 9, с. 77). Но именно вера в Христа, объединяющая людей «единомыслием любви» (Т. 9, с. 78), спасительна для человечества. Такова позиция автора романа и его «светлых» героев.

Оппозиция сад/город проецируется на «расстановку сил» в маленьком дружеском кружке: Синтянина, Катерина Форова и даже майор Форов разделяют мысли отца Евангела, то есть они с ним согласны, они - «в саду», а находящаяся в душевном смятении Лариса Висленева стремится «в город» (Т. 9, с. 78).

Образ Христа-Спасителя не раз возникает в романе «На ножах». Так, старик Гриневич цитирует слова молитвы Христа в Гефсиманском саду в переломный момент своей жизни, когда решился отказаться от места, обещанного генералом Синтяниным (Т. 8, с. 112). Душевные силы, помогающие ему не поддаться искушению, герой черпает в вере, понимая искупительную жертву Христа.

Глафира Бодростина использует образ Гефсиманского сада в ироническом высказывании: «Ть сюда и призван совсем не для того, итобы спать или развивать в висленевской Гефсимании твои примирительнье теории» (Т. 8, с. 174) (диалог с Павлом Гордановым). Однако ирония героини исчезает, когда стремительно приближается развязка действия: «и в сердие ее шевелилось нечто вроде молитвы: да идет сия чаша мимо» (Т. 9, с. 142). Христианский образ-символ чаши акцентирует идею спасительной жертвы Христа.

Образ Христа как символ жертвенного служения людям и спасения человечества прочно ассоциируется в сознании читателей с образом Александры Синтяниной, 
героини, которую можно назвать «светской праведницей». Она, решившись на свой подвиг-жертву, мысленно обращается к Христу: «Предо мной стоял Христос с его великой жертвой» (Т. 8, с. 432). От Него героиня ждет и получает помощь: «Человек, раз твердо и непреклонно решившийся восторжествовать над своею земною природой и слабостями, получает неожиданную помощь, откуда онждал ее» (Т. 8, с. 434).

Жизненный путь героиня проходит, ориентируясь на Христа: она выбирает свой крест и несет его достойно («это иго, которое благо, и бремя, которое легко» (Т. 8, с. 333)). Христос, говоря о своей миссии, произнес: «Ибо иго Мое благо, и бремя Мое легко» (Мф 11: 30).

В этом контексте особенное значение приобретают слова отца Евангела: «со Христом-то [...] легче» творить дела милосердия и «со Христом жестокое-то делать трудней» (Т. 8, с. 201). В данном высказывании соединяются мотивы спасения и Божьего суда. Образ Христа как культурный символ многогранен, и в романе Лескова он присутствует не только как образ Спасителя, но и как образ Бога-судьи. Наиболее ярко эта грань образа-символа и мотив Божьего суда раскрываются в эпизоде гибели Бодростина. «Усльши, Господи, правду мою и не внииди в суд с рабом твоим» (Т. 9, с. 333), - поет молитву над гробом погибшего его бывший слуга Сид Тимофеевич. В повествовании о последующих после убийства графа событиях (смерть Горданова, история Глафиры, Синтяниной, Подозерова, других героев романа) мотив Божьего суда проявляется опосредованно, в рассказе о том, что стало с героями, то есть как рассудил Бог.

Для генерала Синтянина «Христос - заступник на великом и страшном Суде, имеющий право заступиться, так как принес великую жертву» (Т. 9, с. 383). Мотив Божьего суда и образ Христа-судьи развиваются в рассказе героя о жизни. В детстве Христос приходил к нему и «был благ» (Т. 9, с. 383); Он скорбел, когда настигла генерала «бесовская пуля» (Т. 9, с. 383). Лик скорбящего и страдающего Христа Синтянин запомнил на всю жизнь.

Все смысловые грани образа Христа (Спаситель, Судья, Заступник) сводятся воедино в народном понимании Иисуса Христа. Для мужиков Господь «облачается небесами, препоясуется зорями, а вокруг него ангелов больше, чем просяньх зерен в самом большом закроме» (Т. 9, с. 318); «божья сила и власть» (Т. 9, с. 318) необъятны. Такой образ Бога создан в Псалме 103: «Господи, Боже мой! Ты дивно велик, Ты облечен славою и величием. Ты одеваешься светом, как ризою, простираешь небеса, как шатер ...» (Псалтирь, 103: 1-2).

Образ Христа, вездесущего и всемогущего, также актуален в тексте лесковского романа. Данное свойство Господа проявляется в повествовании о судьбоносных для героев событиях. Так, явление Христа и неверие Фомы упомянуты Форовым в разговоре с Гордановым: «Пока не вложу перста моего - ничего не знаю» (Т. 8, с. 152. Ср. Иоанн, 20-25). Евангельские эпизоды предвосхищают духовное перерождение «старого нигилиста».

Аллюзия на евангельский сюжет исцеления расслабленного содержится в письме отца Евангела. В нем он пишет о смерти Ларисы: по его мнению, героиня хотела «освободить» Горданова от бесовского влияния (Т. 9, с. 389). 
Другая известная евангельская сцена, когда немой заговорил $($ Мф 9, 33), проецируется на эпизод с глухонемой Верой Синтяниной, обличающей преступников (Т. 9, с. 358).

Цитаты и реминисценции из библейских текстов в романе «На ножах» соотносятся с его сюжетными линиями, мотивным комплексом, образной системой. Они воспринимаются обобщенно-символической характеристикой описанных событий и становятся выражением авторской точки зрения. Например, измененная евангельская цитата в высказывании Глафиры: «и когда вода будет возмущена» (Т. 8, с. 177), - предвосхищает развитие действия. В ней содержится негативная оценка поступков персонажей, нарушающих мирное течение жизни провинциального городка, преступающих законы человеческого бытия. Аллюзия на эпизод исцеления Христом больных (см. Иоанн 5, 1-9) не только прямо указывает на предстоящие события, спровоцированные героями-«негилистами», но и косвенно выражает авторское пророчество: за «возмущением воды» неизбежно следует исцеление. Данная аллюзия формирует более масштабный - социально-исторический - контекст романа: «современная действительность с ее разнообразными әлементами, взбаламученными недавним иелебным возмущением водъ» (Т. 9, с. 192). В своих социально-политических прогнозах автор оптимистичен: Россия больна, но ее исцеление неизбежно.

В сюжетосложении романа преломляются многие евангельские мотивы: сюжет Александры Синтяниной содержит мотив «жизненного креста»; сюжет Ларисы Висленевой строится в соответствии с триадой: до грехопадения - падение/ грех - очищение (в данном случае третий фрагмент сюжета намечен).

Универсальным сюжетообразующим мотивом в «На ножах» является евангельский мотив «жизнь - путь». По слову Господа: «Я есмь Путь» (Иоанн, 14, 6), - у человека может быть один Путь - это сам Господь. На этом «узком» (Мф, 7, 14) пути христианину следует много трудиться, чтобы преодолеть препятствия. Каждый герой романа проходит свой жизненный путь: генеральша Синтянина, Андрей Подозеров, Катерина Форова и другие - к Христу к возрождению и спасению души; Иосаф Висленев, Глафира Бодростина, Кишенские - к Антихристу, к духовной гибели, к смерти души.

Мотив «жизнь - путь» соотносится с мотивом «блудного сына». Человеку «блудному сыну» - надо встать и идти в Отчий дом с покаянием, Отец встретит его уже тогда, когда он будет «еще далеко» (Лк, 15, 20) от дома. Главное - человек должен проявить волю и устремиться к духовному спасению, встать на путь, указанный Господом («Встану, пойду к Отцу моему» - Лк, 15, 18). Мотив «блудного сына» реализуется в судьбах генерала Синтянина, майора Форова, отчасти - Ларисы Висленевой.

Образ Христа, аллюзии на евангельский и - шире - библейский текст, цитирование, введение библейских мотивов и образов убеждают в том, что мир, в котором живут герои романа Лескова, - христианский мир. Человеком в художественном мире романа «На ножах» движет «неодолимая тяга к постижению 
высшего счастья в соревновании существу, нас превышающему в своей силе правдь, добра и самоотвержения» (Т. 9, с. 221).

Таким образом, в романе Лескова «На ножах» образ-символ Христа соотносится с проблематикой, системой образов, сюжетом, мотивами. Он присутствует в тексте как идеал совершенного человека, осуществившего достойное бытие, воплотившего идеи добра и красоты в их христианском понимании. Содержание образа-символа Христа полно выражает авторское мировосприятие и понимание человека.

Образ Христа - поэтическое средство формирования символического пространства романа «На ножах», значимой для данного произведения формы представленности контекстуального содержания. Необходимые в содержании образа Христа смыслы актуализируются внутренним контекстом сюжетной ситуации, словесной иконографией и «евангельским текстом». Функционирование образа-символа Христа в романе обеспечивается поэтическими приемами: упоминанием, именованием, цитатами, реминисценциями, аллюзиями, сравнением, контрастом и др. Образ-символ Иисуса Христа центрирует символическое пространство романного текста: вокруг него сосредоточиваются христианские смыслы, ценности, образы, мотивы, формирующие и представляющие христианский контекст произведения.

\section{Literatura}

KOLESNIKOVA, V. S.: Pravoslavnyj hram. Simvolika i tradicii. Moskva: OLMA-PRESS, 2006. 540 c.

LESKOV, N. S.: Na nozhah. Leskov N. S. Sobr. soch.: V 12 t. - T. 8-9. Moskva: Izd-vo «Pravda», 1989.

Neizdannyj Dostoevskij: Zapisnye knizhki i tetradi 1860-1881 gg. AN SSSR. In-t mirovoj lit. im. A. M. Gor'kogo. Red. I. S. Zil'bershtejn - L. M. Rozenblyum. V podgot. toma k pech. prinimala uchastie F. I. Grinberg; Podbor il. N. D. Efros pri uchastii G. F. Kogan. Moskva: Nauka, 1971. 727 c. (Literaturnoe nasledstvo). URL: http:/ /litnasledstvo.ru/site/book/id/55

RAJGORODSKIJ, L. D.: Ikonopis' $i$ zhivopis'. Ikona $i$ kartina. Vestnik Sankt-Peterburgskogo gosudarstvennogo universiteta. Seriya 15. SPb., 2014. Vyp. 1, c. 126-138 [Elektronnyj resurs]. URL:https:// cyberleninka.ru/article/n/ikonopis-i-zhivopis-ikony-i-kartiny/viewer

STARYGINA, N. N.: Russkij roman v situacii filosofsko-religioznoj polemiki 1860-1870-h godov. Moskva: Yazyki slavyanskoj kul'tury, 2003. 352 c.

TRUBECKOJ, E. N.: Tri ocherka o russkoj ikone. Umozrenie v kraskah. Dva mira v drevnerusskoj ikonopisi. Rossiya v ee ikone. Novosibirsk, 1991. 112 c. URL: http:/ / lib.ru/CULTURE/TRUBECKOJ/ikony.txt FEDOTOV, G. P.: Social'noe znachenie hristianstva / / Ego zhe. Tyazhba o Rossii. Stat'i 1933-1936. Parizh, 1982. 33 c. URL: http://www.odinblago.ru/soc_zn_hr 
Natalya N. Starygina, professor, doctor of philology

Volga State Technological University

pl. Lenina 3, Yoshkar-Ola, The Mari El Republic, 424000, RU

siarigina@yandex.ru to relevant rights. 
